Бляшевська Алла

кандидат педагогічних наук, доцент, викладач іноземних мов

комунального закладу вищої освіти «Луцький педагогічний коледж» Волинської обласної ради,

м. Луцьк, Україна

ORCID: 0000-0003-3650-932X, e-mail: ablyashevsjka@lpk.ukr.education

Дмитренко Наталія

викладач словесних дисциплін

комунального закладу вищої освіти «Луцький педагогічний коледж» Волинської обласної ради,

м. Луцьк, Україна,

ORCID: 0000-0002-8614-7606

e-mail: nataliyadmytrenko000@gmail.com

Федорець Майя

викладач іноземних мов

комунального закладу вищої освіти «Луцький педагогічний коледж» Волинської обласної ради, м. Луцьк, Україна

ORCID: 0000-0002-2990-4340 e-mail:mfedoretc@gmail.com

\title{
ПРОЄКТНА ДІЯЛЬНІСТЬ У СИСТЕМІ ФОРМУВАННЯ РІДНОМОВНОЇ ТА ІНШОМОВНОЇ КОМУНІКАТИВНОЇ КОМПЕТЕНТНОСТЕЙ МАЙБУТНІХ ФАХІВЦІВ ПОЧАТКОВОЇ ОСВІТИ
}

Анотація. Соціальне замовлення суспільства полягає в тому, щоб фахівець Нової української школи був підготовлений до ефективного виконання своїх професійних функцій і повноцінної участі в усіх сферах суспільного життя. У статті висвітлено актуальне питання організації освітнього процесу вищої школи України, а саме: формування загальних і професійних компетентностей вчителя початкової школи відповідно до вимог закону України «Про освіту», професійного стандарту за професіями «Вчитель початкових класів закладу загальної середньої освіти», «Вчитель 3 початкової освіти (3 дипломом молодшого спеціаліста)». Робота містить огляд основних положень методу проєктів 3 точки зору досягнення основної мети навчання мови (рідної та іноземної) майбутніх педагогів, що передбачає ефективне спілкування в усній та писемній формах мови, користування мовою як засобом міжкультурного спілкування, вміння використовувати мову як інструмент у діалозі

(C) Бляшевська А., Дмитренко Н., 116

Федорець М., 2021 


\section{Інноватика у вихованні. Випуск 13.Том 2. 2021.}

культур i цивілізацій сучасного світу. Авторами обгрунтовано дидактичний потенціал інтерактивних методів навчання, зокрема методу проєктів як складової системи формування комунікативної компетентності студентів вищих закладів педагогічної освіти у процесі вивчення української та англійської мов. Здійснено аналіз і узагальнено досвід роботи викладачів словесних дисциплін Луцького педагогічного коледжу з організації освітнього процесу на прикладі міжпредметного практико-орієнтованого довготривалого проєкту «Леся Українка. Україна. Світ», яким було охоплено студентів 1-4 курсів відділення «Початкова освіта» 3 додатковою кваліфікацією «Вчитель англійської мови в початковій школі». Доведено ефективність методу проєктів у системі формування загальних і професійних компетентностей загалом, а також комунікативної компетентності зокрема студентів вищих закладів педагогічної освіти України.

Ключові слова: професійні компетентності, інноваційні технології навчання, комунікативна компетентність, інтерактивні методи навчання, метод проєктів, проєкт.

Постановка проблеми. Соціальне замовлення суспільства полягає в тому, щоб фахівець Нової української школи був підготовлений до ефективного виконання своїх професійних функцій і повноцінної участі в усіх сферах суспільного життя. Змістом роботи закладів вищої освіти педагогічного профілю України в сучасних умовах $є$ «всебічний розвиток, виховання і соціалізація особистості, яка здатна до життя в суспільстві та цивілізованої взаємодії з природою, має прагнення до самовдосконалення і навчання впродовж життя, готова до свідомого життєвого вибору та самореалізації, відповідальності, трудової діяльності та громадянської активності (Закон України «Про освіту»).

У реаліях глобального інформаційного суспільства зростають вимоги до системи фахової підготовки вчителів початкової школи. Затверджений наприкінці 2020 року професійний стандарт за професіями «Вчитель початкових класів закладу загальної середньої освіти», «Вчитель 3 початкової освіти (з дипломом молодшого спеціаліста)» втілює сучасний підхід до визначення переліку та опису загальних i професійних компетентностей вчителя. До переліку професійних компетентностей увійшли: мовно-комунікативна, предметно-методична, інформаційноцифрова, психологічна, емоційно-етична, педагогічне партнерство, інклюзивна, здоров'язбережувальна, проєктувальна, прогностична, організаційна, оцінювально-аналітична, інноваційна, рефлексивна, здатність до навчання впродовж життя (Професійний стандарт).

Таким чином, як свідчить аналіз державних нормативно-правових актів $з$ питань сучасної освіти, особливої значущості набуває питання активного впровадження інноваційних технологій, а саме, методу проєктів у системі професійної підготовки фахівців освіти загалом і вчителів початкової школи зокрема. 


\section{Інноватика у вихованні. Випуск 13.Том 2. 2021.}

Аналіз останніх досліджень 3 проблеми. Питання формування комунікативної компетентності суб'єктів освітнього процесу досліджували видатні педагоги та лінгвісти М. Бунаков, Ф. Буслаєв, В. Водовозов, К. Ушинський, В. Сухомлинський. Значний внесок у методику розвитку мовлення зробили Л. Авдоніна, М. Баранов, Б. Головін, Т. Ладиженська, М. Львов, Б. Панов, М. Рибнікова, А. Тєкучов, С. Чавдаров, Я. Стельмахович. На комунікативній спрямованості процесу навчання мови наголошували Т.Донченко, А. Купалова та інші дослідники. Сутність і структуру іншомовної професійної комунікативної компетенції з'ясовували А. Андрієнко, Г. Архипова, Н. Гез, С. Козак, О. Павленко, Н. Пруднікова, Ю. Федоренко, Н. Чернова та ін.

Сучасна методична наука рекомендує процес навчання мови як рідної, так й іноземної спрямовувати на формування мовленнєвих умінь і навичок, вироблення комунікативної компетентності в результаті залучення здобувачів освіти до вирішення мовно-мовленнєвих завдань на основі інтерактивних методів навчання (Ф. Бацевич, Л. Варзацька, М. Вашуленко, Л. Мельничайко, М. Пентилюк, М. Наумчук, О. Савченко, Л. Скуратівський, М. Тимчак, Г. Шелехова).

Мета статті - розкрити освітній потенціал методу проєктів як інноваційної технології в системі формування комунікативної (рідномовної, іншомовної) компетентності студентів вищих закладів педагогічної освіти на прикладі реалізації навчального проєкту «Леся Українка. Україна. Світ».

Виклад основного матеріалу дослідження. Зміст сучасного освітнього процесу визначений як формування ключових компетентностей, необхідних кожній людині для успішної життєдіяльності, зокрема: вільне володіння державною мовою; здатність спілкуватися рідною (у разі відмінності від державної) та іноземними мовами; інноваційність; інформаційно-комунікаційна компетентність; навчання впродовж життя; культурна компетентність. Спільними для всіх компетентностей $\epsilon$ такі вміння, як читання 3 розумінням, уміння висловлювати власну думку усно і письмово, критичне та системне мислення, здатність логічно обгрунтовувати позицію, творчість, ініціативність, вміння конструктивно керувати емоціями, оцінювати ризики, ухвалювати рішення, розв'язувати проблеми, здатність співпрацювати з іншими людьми (Закон України «Про освіту»).

Отже основною метою навчання мови (рідної та іноземної) майбутніх педагогів є формування комунікативної компетентності, що означає оволодіння мовою як засобом міжкультурного спілкування, вміння використовувати мову як інструмент у діалозі культур і цивілізацій сучасного світу. Це передбачає ефективне спілкування в усній (говоріння, аудіювання) та писемній (читання, письмо) формах у межах визначення комунікативних сфер, тематики ситуативного мовлення та на основі засвоєного мовного і мовленнєвого матеріалу. 


\section{Інноватика у вихованні. Випуск 13.Том 2. 2021.}

Продуктивність комунікації, тобто вміння спілкуватися 3 метою обміну інформацією, залежить від результативного виконання цілого комплексу завдань: отримувати інформацію, передавати інформацію, досягати поставленої мети шляхом переконання співрозмовника та спонукання його до дії, отримувати додаткову інформацію про співрозмовника на основі знань про об'єктивні закономірності функціонування мови в суспільстві з метою визначення рівня соціальнокультурного розвитку людини, здійснювати позитивну самопрезентацію, тобто справляти приємне враження на співрозмовника або читача на основі володіння культурою мовлення (Пентилюк, 2003, с. 192).
Дослідники
В. Аннушкін,
В. Бєломорець,
А. Капська, Ю. Рождєствєнський та інші відзначають, що рівень комунікативної компетентності суб'єктів освітнього процесу не завжди виправдовує ті зусилля, які затрачаються на їхнє формування, i пояснюють це недостатньою розробленістю інтерактивних педагогічних технологій формування та вдосконалення комунікативних умінь і навичок на заняттях мови (рідної чи іноземної). Науковці наголошують на складності процесу формування комунікативної компетентності, оскільки мовцем одночасно виконуються кілька операцій: аналіз мовленнєвої ситуації, добір лексичного варіанта мови, вибір стилю мовлення, граматичне конструювання висловлювання, логіко-композиційне конструювання тексту, врахування реакції слухачів або читачів на мовлення. Саме тому необхідність реалізації комунікативно-діяльнісного принципу навчання мови у сучасній школі шляхом упровадження інтерактивних освітніх технологій є очевидною та актуальною.

Метод проєктів - це інтерактивна педагогічна технологія, що передбачає постановку реальної проблеми, практично важливої для студента, для вирішення якої необхідні побудова алгоритму пошуку інформації, проведення дослідження, аналіз його результатів, створення нового кінцевого продукту, порівняння його 3 існуючим культурним зразком, оцінка його інновативності, презентація проєкту. Використання цього методу у педагогіці обгрунтоване в працях зарубіжних (Дж. Дьюї, В. Кілпатрика, Е. Коллінгс, Т. Хатчинсон) та вітчизняних науковців (М. Вашуленко, Г. Ващенко, В. Ігнатьєва, Р. Нємов, Л. Пироженко, I. Підласий, Є. Полат, О. Пометун, Л. Рубінштейн, А. Спіркін, В. Сластєнін, Л. Фрідман, А. Хуторський, С. Шацький, В. Шульгін, Г. Щукіна та ін.).

Аналіз науково-методичних джерел засвідчує, що проєктні технології стали дієвим чинником підвищення ефективності освітнього процесу в початковій, середній, вищій ланці освіти. Водночас доводиться констатувати, що недостатньою мірою висвітлено питання використання методу проєктів у процесі формування та вдосконалення професійних компетентностей майбутніх педагогів, в тому числі комунікативної компетентності. 


\section{Інноватика у вихованні. Випуск 13.Том 2. 2021.}

Найбільш поширене визначення методу проєктів таке: система навчання, за якої здобувачі освіти набувають знання, уміння і навички у процесі планування й виконання практичних завдань-проєктів, що постійно ускладнюються. Під час роботи за методом проєктів на чільне місце ставиться самодіяльність здобувачів освіти та їхня активність, ініціативність, захопленість (Вашуленко, 2010, с. 9).

Є. Полат підкреслювала прагматичну спрямованість на результат проєкту. Аби досягти такого результату, необхідно навчити здобувачів освіти самостійно мислити, знаходити i вирішувати проблеми, використовуючи для цього знання 3 усіляких галузей, уміння прогнозувати результат i можливі наслідки багатоваріантних рішень, уміння встановлювати причинно-наслідкові зв'язки (Полат, 2004).

Сам процес проєктної діяльності позитивно впливає на розвиток здобувачів освіти i на різні сфери педагогічної діяльності: знання перестають бути метою, а стають засобом освіти; пошук розв'язку практичних завдань актуалізує необхідність набуття знань; поєднання пізнавальної, дослідницької і перетворювальної діяльності підвищує рівень засвоєння знань і умінь; навчальний матеріал сприймається цілісно та 3 орієнтацією на створення певного продукту; учасники проєкту отримують нові, нетрадиційні знання, вміння та навички; здобувачі освіти виходять зі звичного дидактичного середовища, виконуючи завдання, в яких відсутній єдино правильний розв’язок; використання знань та вмінь відбувається на рівні інтеграції; пошук необхідної інформації спонукає до систематичної роботи з довідковою літературою (Бойко, 2014).

Таким чином, сутність проєктної педагогічної технології полягає у функціонуванні цілісної системи дидактичних засобів (змісту, методів, прийомів тощо), що адаптує освітній процес до структурних та організаційних вимог навчального проєктування. Воно, зі свого боку, передбачає системне і послідовне моделювання тренувального вирішення проблемних ситуацій, які потребують від учасників освітнього процесу пошукових зусиль, спрямованих на дослідження і розробку оптимальних шляхів вирішення завдань, неодмінний захист кінцевого продукту, притому обов'язково особистісно або суспільно важливого, аналіз підсумків проєкту.

Інноваційність методу проєктів зумовлює використання інформаційно-комунікаційних технологій. Зокрема, 3 метою пошуку інформації використовуються пошукові інтернет-сервери та машини, для проведення аналізу результатів дослідження застосовуються програми excel та word, а для підготовки кінцевого продукту та його презентації передбачається використання програм powerpoint тa publisher.

3 іншого боку, дидактична цінність цієї освітньої технології визначається тим, що мовленнєве спілкування вплетене в інтелектуальноемоційний контекст іншої діяльності (Зимняя, 2007), тобто відбувається не просто дія, вплив одного суб'єкта на інший, а саме їх взаємодія, співпраця. 
На наше переконання, метод проєктів є одним із найбільш дієвих засобів оптимізації процесу формування комунікативної компетентності студентів вищих закладів педагогічної освіти, оскільки базується на принципах особистісно-діяльнісного підходу до навчання, активізації можливостей особистості, передбачає наявність суб'єктно-суб'єктних відносин, коли студент виступає не об'єктом, а суб'єктом навчання в умовах спілкування на засадах співпраці.

Прикладом може слугувати система роботи Луцького педагогічного коледжу, де проєктні технології $є$ органічною складовою освітнього процесу i значною мірою забезпечують ефективність формування комунікативної компетентності студентів: процес оволодіння мовним матеріалом та мовленнєвими навичками здійснюється в контексті виконання індивідуальних творчих завдань; студенти (у складі груп або індивідуально) творчо працюють над виконанням особисто значущого для них проєктного завдання, у якому кожен одержує свою ділянку роботи відповідно до особистих інтересів, нахилів, талантів; студенти самі добирають необхідний матеріал, у тому числі мовно-мовленнсвий, планують зміст своєї діяльності та здійснюють іiі, досягаючи потрібного результату, що демонструється не оцінкою, а презентацією творчих розробок, буклетів, стінгазет, проведенням конференцій, виставок, показом фільмів, альбомів тощо; викладач діє як організатор, керівник творчого процесу, як джерело ідей та порад.

Упродовж 2020-2021 навчального року з нагоди 150-річчя від дня народження Лесі Українки до участі в міжпредметному практикоорієнтованому довготривалому проєкті «Леся Українка. Україна. Світ» викладачами філологічних дисциплін Луцького педагогічного коледжу було залучено студентів 3-4 курсів відділення «Початкове навчання» 3 додатковою кваліфікацією «Вчитель іноземної (англійської) мови в початковій школі», які отримали базові навички виконання проєктів, а також студентів 1-2 курсу, які набувають початкових навичок проєктної діяльності. Мета проєкту - формування у майбутніх фахівців освіти ключових компетентностей загалом і комунікативної компетентності (рідномовної та іншомовної) зокрема; стимулювання студентів до самостійної навчально-пізнавальної діяльності; забезпечення можливостей для самоосвіти, саморозвитку, самовираження особистості у процесі пошуково-краєзнавчої роботи.

Теоретичною складовою проєкту передбачено виконання програмових вимог із навчальних дисциплін: «Українська мова», «Українська література», «Сучасна українська мова 3 практикумом», «Практичний курс іноземної мови», «Теоретичний курс іноземної мови», «Історія України», «Інформатика», «Методика навчання української мови», «Методика навчання іноземної мови», «Методика навчання інформативної освітньої галузі».

Практична складова проєкту спрямована на формування та вдосконалення у майбутніх учителів початкової школи комплексних 


\section{Інноватика у вихованні. Випуск 13.Том 2. 2021.}

фахових умінь та навичок: загальномовних: орфоепічних, орфографічних, пунктуаційних, лексичних, граматичних, синтаксичних; формування стійкої мотивації до вивчення рідної та іноземних мов; розвиток навичок користування довідковою літературою та іншими джерелами інформації; комунікативно-мовленнєвих: аудіювання, читання, письма, говоріння; українсько-англійського перекладу; дотримання високої культури мовлення (українського й англійського); вироблення умінь і навичок в усіх видах мовленнєвої діяльності (аудіювання, читання, говоріння, письмо) і в різних сферах спілкування (особистісна, публічна, освітня); формування комунікативної компетентності; методичних: добирати відповідні форми і методи навчання, дидактичний матеріал; добирати оптимальні шляхи навчання; працювати 3 навчально-методичною літературою та іншими джерелами інформації; аналізувати, синтезувати, оцінювати отриману інформацію; розробляти план і алгоритм реалізації проєкту; робити аналіз і самоаналіз діяльності у проєкті; постійно удосконалюватись, підвищувати особистий рівень навчальних досягнень (навички саморозвитку); виступати перед аудиторією, аргументовано висловлювати свою думку (комунікативні навички); інформаційнокомунікаційних: працювати 3 інформацією різних видів; створювати та використовувати дієві алгоритми; використовувати програми навчального призначення та інформаційних технологій для навчання молодших школярів; використовувати інформаційні, технічні та методичні засоби навчання в початковій школі; реалізовувати міжпредметні зв'язки засобами інформатики та сучасних інформаційних технологій.

Першим (підготовчим) етапом проєкту передбачено поділ студентів на групи відповідно до їхніх уподобань, опрацювання студентами теоретичного матеріалу, обговорення ключових і тематичних питань: Леся Українка - відома чи невідома? Леся Українка - це символ України? Яку роль відіграла Волинь у долі і творчості Лесі Українки? Яке значення творчої спадщини Лесі Українки для волинян? Чи відома Леся Українка у світі? Чим цікава Леся Українка сучасним українцям? Крім того, визначено алгоритм дослідження, критерії оцінювання результатів проєкту.

Мета другого етапу - дослідження обраних тем, а саме: пошук інформації в науково-методичній літературі, ЗМІ та в мережі Інтернет; опитування жителів Луцька та області; консультації 3 науковцями, краєзнавцями, письменниками, видавцями; екскурсії в Музей Лесі Українки Волинського національного університету, Колодяжненський літературно-меморіальний музей Лесі Українки. Результати дослідження обговорено у колі однокурсників та викладачів.

Мета третього етапу - популяризація результатів проєкту і подальше його розширення: презентація українсько-англійського путівника «Лесині стежки Волині»; літературно-мистецьке дійство «У Лесиній вітальні» для студентів і учнів старших класів; виховний захід «Лесине свято» для учнів початкових класів; випуск чергового примірника газети «Вісник 


\section{Інноватика у вихованні. Випуск 13.Том 2. 2021.}

коледжу», присвяченого ювілею письменниці. Здобутки проєкту репрезентуються на сторінках інформаційних бюлетенів, газети «Вісник коледжу», в методичних посібниках та розміщуються в інтернет-сайті коледжу.

Підсумки реалізації проєкту «Леся Українка. Україна. Світ» дозволяють дійти висновку, що засобами інтерактивних технологій створено умови для організації освітньо-розвивального середовища на основі збагачення програмового змісту рідномовної та іншомовної освіти особистісно вагомим змістом, в якому студенти є активними суб'єктами індивідуального професійного становлення; оцінки і самооцінки способів продуктивної навчальної діяльності; засвоєння нових знань студентами на основі набутого суб'єктивного досвіду; структурування навчального матеріалу, забезпечення можливостей використання інформаційнокомунікаційних технологій, вибору змісту, виду та форми для виконання індивідуальних завдань-проєктів відповідно до наявного суб'єктивного досвіду; формування комунікативної (рідномовної та іншомовної) компетентності майбутніх педагогів; активного стимулювання студентів до самостійної навчально-пізнавальної діяльності, забезпечення можливостей для самоосвіти, саморозвитку, самовираження у процесі здобуття фахової освіти.

Ефективність проєкту підтверджується значним покращенням якості підготовки фахівців початкової школи, про що свідчать результати контрольних робіт, семестрових іспитів з навчальних дисциплін, а також підвищення теоретичного i практичного рівня проведення занять у початковій школі студентами 3-4 курсу в рамках педагогічної практики (виховної і пробної).

Висновки і перспективи подальших розвідок. Досвід реалізації методу проєктів у системі фахової підготовки майбутніх фахівців освіти в Луцькому педагогічному коледжі засвідчує, що при раціональному плануванні, організації та управлінні самостійною та науководослідницькою роботою студентів на основі методу проєктів суттєво підвищується ефективність освітнього процесу та зростає якість підготовки спеціалістів для сучасної школи. Усвідомлення студентами думки, що в діяльності педагога гармонійно поєднуються теоретичні знання та мистецтво, нормативні елементи і креатив, стає рушійною силою для постійної самоосвіти, вдосконалення професійних компетентностей. Тому, на наше глибоке переконання, метод проєктів $є$ інноваційною педагогічною технологією, здатною виконати одне 3 найважливіших стратегічних завдань на етапі модернізації вищої освіти України - забезпечення високого рівня загальних і професійних компетентностей вчителя для Нової української щколи.

Незважаючи на різнобічність досліджень процесу організації проєктної діяльності та теоретико-практичну важливість методу проєктів як ефективної інноваційної педагогічної технології, питання розробки 


\section{Інноватика у вихованні. Випуск 13.Том 2. 2021.}

цілісної методичної системи реалізації методу проєктів у практиці вищої фахової освіти України потребує подальшої розробки.

\section{СПИСОК ВИКОРИСТАНИХ ДЖЕРЕЛ}

Закон України «Про освіту». URL: https://zakon.rada.gov.ua/laws/show/2145-19. [Дата звернення 25.12.20].

Професійний стандарт за професіями «Вчитель початкових класів закладу загальної середньої освіти», «Вчитель з початкової освіти (з дипломом молодшого спеиіаліста)». URL: https://mon.gov.ua/ua/ news/zatverdzheno-profstandart-vchitelya-pochatkovih-klasiv-vchitelyazakladu-zagalnoyi-serednoyi-osviti-i-vchitelya-z-pochatkovoyi-osviti. [Дата звернення 25.12.20].

Пентилюк, М. (2003). Практикум з методики навчання украӥнської мови. К.: Ленвіт, С.192.

Методика навчання украӥнської мови в початковій школі / за наук. ред. М. С. Вашуленка. К.: Літера ЛТД, 2010. С. 9.

Полат, Є. (2000). Метод проектів. Нові педагогічні та інформаційні технології в системі освіти /під ред. Є.С.Полат. M., URL: https://docplayer.ru/31697722-Metod-proektov-d-p-n-prof-polat-e-s-ioso-rao-kistorii-voprosa.html. [Дата звернення 25.12.20].

Бойко, Л. Актуальність методу проєктів у початковій школі. URL: https://novashkola.ucoz.ua/publ/metod_proektiv_z_vlasnogo_dosvidu_roboti/11-0-9. [Дата звернення 25.12.20].

Зимняя, И. (2009). Педагогическая психология. Москва: Университетская книга; Логос. 384 с.

Вороненко, Т. Класифікачія навчальних проєктів. URL: http://ipvid.org.ua/upload/iblock/20c/20c207b21906f87eb050de396d9b5a55.pd f. [Дата звернення 25.12.20].

Пометун, О., Пироженко, Л. (2004). Сучасний урок. Інтерактивні технологї навчання. К.: Видавництво А. С. К. 192 с.

Тимчак, М. (2019). Позааудиторна робота як засіб формування іншомовної компетентності студентів. Початкова школа. № 5. С. 9-13.

\section{REFERENCES}

Zakon Ukrainy "Pro osvitu". [Law of Ukraine "On Education”] URL: https://zakon.rada.gov.ua/laws/show/2145-19. Data zvernennia 25.12.20]. [in Ukrainian].

Profesiinyi standart za profesiiamy "Vchytel pochatkovykh klasiv zakladu zahalnoi serednoi osvity", "Vchytel z pochatkovoi osvity (z dyplomom molodshoho spetsialista)». [Professional standard by professions "Primary school teacher of general secondary education", "Primary education teacher (with a diploma of a junior specialist)"]URL: https://mon.gov.ua/ua/news/zatverdzheno-profstandart-vchitelya-pochatkovihklasiv-vchitelya-zakladu-zagalnoyi-serednoyi-osviti-i-vchitelya-z-pochatkovoyi -osviti. [Data zvernennia 25.12.20]. [in Ukrainian]. 


\title{
Інноватика у вихованні. Випуск 13.Том 2. 2021.
}

Pentyliuk, M. (2003). Praktykum z metodyky navchannia ukrainskoi movy. [Workshop on methods of teaching the Ukrainian language] K.: Lenvit, S.192. [in Ukrainian].

Vashulenko, M. (2010). Metodyka navchannia ukrainskoi movy $v$ pochatkovii shkoli / za nauk. red. M. S. Vashulenka. [Methods of teaching the Ukrainian language in primary school] / za red. M Vashulenko. K.: Litera LTD, S. 9. [in Ukrainian].

Polat Ye. (2000). Metod proektov. Novi pedahohichni ta informatsiini tekhnolohikh $v$ systemi osvity/pid red. E.S.Polat. [Project method. New pedagogical and information technologies in the education system] za red. Polat E. M., URL: https://docplayer.ru/31697722-Metod-proektov-d-p-n-prof-polat-es-ioso-rao-k-istorii-voprosa.html. [Data zvernennia 25.12.20]. [in Ukrainian].

Boiko, L. Aktualnist metodu proektiv u pochatkovii shkoli. [Relevance of the project method in primary school] URL: https://novashkola.ucoz.ua/publ/metod_proektiv_z_vlasnogo_dosvidu_roboti/1 1-0-9. [Data zvernennia 25.12.20]. [in Ukrainian].

Zimniaia, Y. A., (2009). Pedahohycheskaya psykhologiya. [Pedagogical psychology]. M: Universitetskaya kniga; Logos. 384 p. [in Russian].

Voronenko, T. Klasyfikatsiia navchalnykh proektiv [Classification of educational projects] URL: http://ipvid.org.ua/upload/iblock/20c/20c207b 21906f87eb050de396d9b5a55.pdf. [Data zvernennia 25.12.20]. [in Ukrainian].

Pometun, O., Pyrozhenko L. (2004). Suchasnyi urok. Interaktyvni tekhnolohii navchannia. [Modern lesson. Interactive learning technologies] K.: Vydavnytstvo A. S. K. 192 p. [in Ukrainian].

Tymchak, M. (2019). Pozaaudytorna robota yak zasib formuvannia inshomovnoi kompetentnosti studentiv [Extracurricular work as a means of forming foreign language competence of Primary School teachers]. Pochatkova shkola. No 5. P. 9-13. [in Ukrainian].

\section{PROJECT ACTIVITY IN THE SYSTEM OF FORMATION OF NATIVE LANGUAGE AND FOREIGN LANGUAGE COMMUNICATIVE COMPETENCIES OF THE FUTURE PRIMARY EDUCATION SPECIALASTS}

\author{
Alla Bliashevska \\ Candidate of Pedagogical Sciences, Associate Professor, \\ foreign language teacher, \\ Communal institution of higher education "Lutsk \\ Pedagogical College" of Volyn Regional Council, \\ Lutsk, Ukraine \\ ORCID: 0000-0003-3650-932X \\ e-mail: ablyashevsjka@lpk.ukr.education \\ Nataliia Dmytrenko \\ teacher of philological disciplines, \\ Lutsk Pedagogical College,
}


Lutsk, Ukraine

ORCID: 0000-0002-8614-7606

e-mail: nataliyadmytrenko000@gmail.com

Maiia Fedorets

foreign language teacher, Communal institution of higher education "Lutsk Pedagogical College" of Volyn Regional Council,

Lutsk, Ukraine

ORCID: 0000-0002-2990-4340

e-mail: mfedoretc@gmail.com

Abstract. The social order of the society is readiness of the specialist of the New Ukrainian School to be prepared to perform her professional functions effectively and to participate fully in all spheres of life.

The article covers the topical issue of organizing the educational process of higher education in Ukraine, namely the formation of general and professional competencies of primary school teachers in accordance with the requirements of legal regulations: the Law of Ukraine "On Education", qualification standard for professions "Primary school teacher", "Teacher for Primary education (with a diploma of junior specialist)". The paper provides an overview of the main provisions of the project method in terms of achieving the main goal of teaching language (native and foreign) of future teachers, which means effective communication in oral and written speech, use of language as the means of intercultural communication, the ability to use language as a tool in the dialogue of cultures and civilizations of the modern world. The authors have substantiated the didactic potential of interactive teaching methods, in particular the project method, as a component of the system of formation the students' communicative competence in higher educational institutions in the process of learning Ukrainian and English languages. The analysis and the generalization of the experience of language teachers in Lutsk Pedagogical College are fulfilled as to the organization of the educational process on the example of interdisciplinary practice-oriented long-term project "Lesia Ukrainka. Ukraine. World", which involved students of 1-4 courses of the department "Primary Education" with the additional qualification "English language teacher in primary school". The effectiveness of the project method is proved in the system of formation of general and professional competencies in general, as well as communicative competence of students of higher educational institutions in Ukraine in particular.

Keywords: professional competences, innovative learning technologies, communicative competence, interactive teaching methods, project method, project.

Стаття надійшла до редакиії 22. 02. 2021 р. 